PRZEGLĄDY - POLEMIKI - MATERIAEY

Kwartalnik Historyczny Rocznik CXXVII, 2020, 2 PL ISSN 0023-5903

\author{
DARIUSZ ROLNIK \\ https://orcid.org/0000-0002-7649-3142 \\ Uniwersytet Śląski w Katowicach
}

\title{
RZECZ O LEONARDZIE MARCINIE ŚWIEYKOWSKIM - W ODPOWIEDZI NA RECENZJĘ ZOFII ZIELIŃSKIEJ*
}

Nie ma książki ani dobrej w każdym szczególe, ani całkowicie złej․ Moja książka - jak można wnioskować z treści recenzji i konkluzji autorstwa Zofii Zielińskiej - nie podlega jednak tej prawdzie. Mam tylko nadzieję, że spodobała się Recenzentce estetyka książki, okładka i krój czcionki. Uważam, że źle się dzieje, jeżeli wartość ocenianej publikacji mierzy się wyłącznie liczbą błędów; to nie dyskusja naukowa, a pod jej przykryciem próba uprawiania zaściankowej i partykularnej „polityki naukowej”.

Niestety, do takiego przekonania przywiódł mnie już na wstępie lektury błąd Recenzentki, która (nie wiem, jak kwalifikować tę omyłkę: jako przejęzyczenie? „kompromitującą” usterkę warsztatową w odczycie druku, nie rękopisu? a może jako lapsus wynikający z nastawienia albo uprzedzenia Recenzenta do recenzowanego tekstu? - zachowuję nadzieję, że nie personalnego, odnoszonego bezpośrednio do mnie) recenzentem wydawniczym mojego opracowania uczyniła Dariusza Nawrota. Ten na etapie manuskryptu pracy nie widział i nie miał z nią nic wspólnego, w związku z tym to bynajmniej nie jego nazwisko figuruje wśród recenzentów. „Co zatem sądzić o innych ustaleniach” (s. 596),

* W odpowiedzi na recenzję Zofii Zielińskiej, D. Rolnik, Leonarda Marcina Świeykowskiego (1721-1793) ostatniego wojewody podolskiego życie codzienne i publiczne oraz jego myśli o Rzeczypospolitej, Katowice 2016, KH 126, 2019, 3, s. 592-600.

1 „Nullus est liber tam malus, ut non aliqua parte prosit” - żadna książka nie jest tak zła, aby pod jakimś względem nie przynosiła pożytku. Maksyma Pliniusza Starszego zapisana przez jego adoptowanego syna Pliniusza Młodszego w Epistulae III, 5, 10, w: Dicta. Zbiór łacińskich sentencji, przysłów, zwrotów, powiedzeń, z indeksem osobowym i tematycznym, oprac. C. Michalunio SJ, Kraków 2010, s. 412. 
w tym przypadku tych poczynionych $\mathrm{w}$ recenzji? Nieuzasadniona jest również uwaga o drugim recenzencie: „Czy mogę wierzyć, że ten ceniony i zasłużony wydawca, wytrawny znawca źródeł, rzucił okiem na część edytorską?" (s. 600). Otóż Michał Zwierzykowski nie recenzował „wydawnictwa źródłowego", a biografię Leonarda Marcina Świeykowskiego, druga jej część liczy 90 stron (z notą edytorską i przypisami) i jest właściwie aneksem włączonym w całość w celu zobrazowania poglądów ostatniego wojewody, co przecież zostało we wstępie wskazane: „z uwagi na ten ostatni rozdział do opracowania dodano drugą część, ilustrującą poglądy polityczne”. Recenzent nie miał obowiązku jeździć „trop w trop” za autorem i sprawdzać, czy nie została pominięta jakaś litera, końcówka wyrazu bądź fraza. Autor nie mógł też dostarczyć cyfrowych zapisów cytowanych w biografii źródeł, w tym także tego źródłowego aneksu, bo nim po prostu nie dysponował, materiał do biografii Świeykowskiego był gromadzony przez lata, również jeszcze przed nastaniem epoki cyfrowej, z wszystkimi ograniczeniami z tego płynącymi. Ponadto jest oczywiste, że merytorycznie za wersję finalną publikacji zawsze odpowiada autor, nie recenzent wydawniczy, nie chciałbym więc, by padł cień na rzetelność obu moich recenzentów, wszelkie przygany wobec nich uważam nie tylko za niezasłużone, ale również po prostu za nieeleganckie. Niemniej, podejście Recenzentki do kwestii recenzentów wydawniczych wskazuje na stronniczość recenzji, która nie ma w tym wypadku oceniać pracy, a jedynie ją zdyskredytować.

Przechodzę do konkretnych zarzutów uczynionych przez Recenzentkę. Praca o Świeykowskim, owszem, jest rozprawą źródłową, natomiast ów dodatek, „druga część” przeze mnie rozumiana jako aneks źródłowy, miał obrazować pewien proces rozwoju myśli politycznej bohatera rozprawy i miał dokumentować moje autorskie interpretacje tych myśli, i tyle. Każdy ma prawo odczytywać je inaczej, mając do dyspozycji teksty wypowiedzi Świeykowskiego na tematy polityczne. Chciałem również, aby dzięki temu aneksowi tytułowy bohater książki zaistniał w badaniach nad kwestiami polskiej myśli politycznej, by jego postać zwróciła uwage na to, że o sprawach państwa myślało wielu, a nie tylko grono paru wybranych myślicieli, wokół których toczyła się dyskusja, przecież nie tylko oni w niej uczestniczyli. Aneks nie jest wydawnictwem źródłowym, choć jako takie wcześniej był przewidywany w innym wydawnictwie. Do realizacji tego zamysłu nie doszło ${ }^{2}$, a ja - przyznaję, nie weryfikując

${ }^{2}$ Mam wątpliwości co do trafności praktyk wydawania małych prac źródłowych oraz ponownych edycji poprawionych wydawnictw źródłowych - w odniesieniu do czasów nowożytnych - najczęściej dziewiętnastowiecznych. 
zapisu raz odczytanego - prawie w ostatniej chwili włączyłem ten dodatek do biografii Świeykowskiego właśnie o takim, jak wyżej wspomniałem, charakterze. Przyznaję, co było moim błędem, że większość oryginałów czytałem raz, po prostu je przepisując i nie dostrzegając problemów z odczytaniem, stąd błędy literowe, do których się przyznaję i w tym zakresie krytykę przyjmuję, jednak nie zgadzam się z interpretacją tych błędów przez Recenzentkę. Ten wstęp jest istotny, bowiem większość krytycznych uwag Zielińskiej odnosi się właśnie do tej części. Uwagi poczynione przez Recenzentkę poprawiają tekst źródła, jego błędny odczyt, ale te korekty nie zmieniają wydźwięku i znaczenia przekazu. W prawie żadnym momencie moje błędy nie zmieniły wymowy przekazu ani jego wartości merytorycznej. Tylko w dwóch miejscach można mieć wątpliwości co do odczytu fraz i tłumaczeń z łaciny, z czym oczywiście się zgadzam. Co się tyczy kwestii Buczacza, to również jest, moim zdaniem, tylko - albo aż - błąd w odczycie, zresztą zostało zaznaczone, że odczyt jest niepewny; w danym momencie faktycznie nie pojawiło się pytanie, gdzie leży Buczacz, ale nie można wnioskować na tej podstawie, że nie znam jego położenia, na trakcie „do Strusowa” umieściłem go po prostu bezrefleksyjnie. Z kolei odnosząc się do Jaworowskiego Jaworskiego, to chyba nieco mniejszy błąd niż wynikałoby to $z$ uwagi Recenzentki. To tylko wymieniona w źródle postać, skądinąd nieznana, inaczej niż na przykład autor sporego korpusu źródeł Wincenty Gurski ${ }^{3}$. Fraza: „kłaniam im się w pas” jako przeze mnie dodana jest zaznaczona odsyłaczem literowym: ${ }^{\mathrm{i}-\mathrm{i}}$, czego $\mathrm{w}$ recenzji nie zauważono. W aneksie, w każdym zapisie czytelnik znajduje odsyłacze do źródła i odczyt może sam skonfrontować z oryginałem, podobnie jak uczyniła to Recenzentka. I jeszcze jedna uwaga o przypisach niepotrzebnych w aneksie. Większość poczynionych wtrętów i przypisów wyjaśnia tekst, czy jednak dla wszystkich badaczy wszystkie poruszane w tym źródle kwestie są oczywiste - mam wątpliwości. Wskazane przez Recenzentkę błędy mieszczą się głównie w tej części, na podstawie jej odbioru sugeruje ona, że i sama biografia jest nierzetelna.

Odnosząc się do kolejnych zarzutów czynionych opracowanej przez piszącego te słowa biografii Świeykowskiego, pozwoliłem sobie je uporządkować, nie do wszystkich odnosząc się szczegółowo. Recenzentka, oceniając moją pracę, zauważyła, że skupia się ona na części politycznej

${ }^{3}$ Cieszę się, że w recenzji został nazwany „Gurskim” a nie „Górskim”, jak czyniono wcześniej, co, niestety, odnotowałem w swej książce, por. D. Rolnik, Leonarda Marcina Świeykowskiego (1721-1793) ostatniego wojewody podolskiego życie codzienne i publiczne oraz jego myśli o Rzeczypospolitej, Katowice 2016, s. 18-19. 
kariery tytułowego bohatera, „bo to dzięki niej ów «człowiek znikąd» zasiadł na poczesnym miejscu w senacie" (s. 593). Błąd. To przecież dzięki zgromadzonemu majątkowi i pozycji ekonomicznej Świeykowski został politycznie doceniony, warto skorelować daty awansów politycznych $z$ datami nabycia przez niego kolejnych dóbr, te drugie wyprzedzają znacznie awanse polityczne. Ponadto biografia ma swoją koncepcję, w której sprawy polityczne są ukazane w jednym rozdziale, a jest ich wszystkich dziewięć, merytorycznie odnoszących się do różnych sfer życia Świeykowskiego.

Recenzentka ocenia bazę źródłową, która jej zdaniem nie daje podstaw do „rozdęcia” pracy. Moim zdaniem również, ale według mnie książka jednak nie jest „rozdęta”. Rozbieżności w ocenie jej rozmiarów wynikają z tego, że Recenzentka patrzy przez pryzmat tylko „kariery politycznej" bohatera. Na nią jednak składa się nie tylko jego polityczna aktywność, ale cała jej otoczka, z koneksjami, udziałem w sądach, pracą około majątku itp. Tę złożoność biografia pokazuje, ale wprowadzenie takich aspektów (celowe, zgodne z zamierzoną koncepcją pracy) skutkowało jej sporymi rozmiarami. Kwestia, czy kariera polityczna poprzedza ekonomiczną i pytania o to, co i w jaki sposób na tę pierwszą wpłynęło, są jednak dla Recenzentki obojętne. O sprawach politycznych można jak sugeruje recenzja - napisać 12 stron, wypełniając je krótkim biogramem - tak uczyniłem, pisząc biogram Świeykowskiego do Polskiego słownika biograficznego, syntetyczny, zgodnie z konwencją przyjętą w tym wydawnictwie ${ }^{4}$. Raz jeszcze powtórzę, że cel i koncepcje recenzowanej pracy były zgoła inne, zatem wymagały poświęcenia Świeykowskiemu zdecydowanie więcej niż ubożuchne 12 stron, czego w recenzji nie zauważono, a także, wyliczając źródła do rozdziału politycznego, nie dostrzeżono w ogóle bazy źródłowej, na której oparte są pozostałe rozdziały. „Lwia część książki jest nie na temat”, pytanie czy uwaga Recenzentki: „na początku przykłady z rozdziału szóstego” (s. 593), coś sugeruje? Nic, bo do rozdziałów wcześniejszych już nie wraca. Recenzentka pisze, że pojawiają się w nim „oczywistości” i „niczym niepodbudowane domysły", to zarzuty zupełnie chybione. W toku narracji nad kolejnymi wątkami muszą się one pojawić, by umiejscowić postać w czasie i przestrzeni, z takim zarzutami nie da się polemizować, bo nie są one trafione w żadnym momencie pracy.

Recenzentka zarzuca mi ignorowanie literatury i powoływanie się na „nieistotne dla sprawy rękopisy” (s. 593). Nie zgadzam się z tymi

${ }^{4}$ Por. D. Rolnik, Świeykowski Leonard Marcin, PSB, t. 51, Warszawa-Kraków 2017, s. 383-388. 
stwierdzeniami. Opracowania są tam, gdzie powinny być i w tworzeniu pracy pomagały. A „nieistotne rękopisy” to przecież źródła, baza pracy badawczej historyka, jako takie zawsze jak najbardziej warte są przywoływania, a tym bardziej w tej pracy, jako że to materiały w większości dotąd nieznane i niewykorzystywane. To z ich treści, wbrew temu, co napisane w recenzji (,Kontekst historyczny jest zarysowany niekompletnie”, „nieistotne rękopisy”), wydobywa się ów kontekst historyczny. Te jakoby „nieistotne rękopisy” to w większości listy i pisma kierowane do Świeykowskiego, pokazują co wiedział, co mógł wiedzieć i z jakiego źródła czy źródeł otrzymywał wieści. A jeżeli w osądzie różnych kwestii się mylił, to m.in. dlatego, że takie szczątkowe czy bałamutne informacje otrzymywał, no i nie mógł sięgnąć do opracowań pióra autorów nam współczesnych... Wydaje mi się, że te źródła są istotne dla biografii człowieka, który czerpał z nich wiedzę (podkreślam: nawet niepełną i niepewną) o tym, co się dzieje w kraju (zauważam: jego nieznajomość, pomyłki i niezrozumienie pewnych spraw dają dobre świadectwo tego, jaka była świadomość tego bohatera i mogą tłumaczyć jego działania). Ponadto, jeśli ktoś nie bierze udziału w pewnych zdarzeniach, nie znaczy to, że one go nie dotykają czy nie interesują. Natomiast moim zadaniem nie było przedstawienie w monograficznym ujęciu zagadnień szczegółowych, jak na przykład sejmiki czy sejm 1786 r.

Zarzut, że podpieram się streszczeniami i / lub cytuję „przypadkowe fragmenty" (s. 593), i nimi wypełniam próżnię, również wynika, moim zdaniem, z niezrozumienia treści pracy przez Recenzentkę. W większości są to teksty, które albo były wysyłane do Świeykowskiego, albo znalazły się w jego archiwum. Dają one pogląd o człowieku, który je odbierał, w wielu momentach nie chodziło bowiem o wyjaśnianie spraw, a właśnie o fakt, co wiedział albo nie mój bohater. Sprawy omawiane i ich historyczny ogląd były w tych fragmentach po prostu zbędne, natomiast niekiedy zakreślały szeroki krąg informatorów Świeykowskiego i, szerzej, jego znajomości. Druga sprawa to kwestia oceny tych tekstów pod kątem wartości źródłowej. Sądzę, że listy Gurskiego w sprawie Marii Dogrumowej są istotnym źródłem do badań nad sejmem 1786 r. i samej „sprawy Dogrumowej”. Inna rzecz, że jakoby nie zostały wykorzystane w mojej rozprawie prace poświęconej tej sprawie, co uważam za zarzut pozbawiony podstaw. Zdecydowanie mniejszy błąd popełnił Świeykowski, nie uczestnicząc w tym sejmie, taki był jego wybór, ale tego Recenzentka nie dostrzega. Wątek Dogrumowej był ważny, bo żyli nim ci, którzy w polityce ówczesnej uczestniczyli, ale również mieli oni dystans do walk fakcyjnych, w większości nie chcąc się do nich mieszać w przekonaniu, że żadnej korzyści im to nie przyniesie. Może to i złe podejście, ale takie właśnie było. 
Wskazywane w recenzji fragmenty pracy „nie na temat” są dla mnie niezrozumiałe. Przykładowo, czy ktoś, kto był marszałkiem Trybunału Koronnego w 1783 r. nie interesował się sprawą tego, kto będzie marszałkiem Rady Nieustającej w 1784 r.? Nawet taki abnegat jak Świeykowski taką ciekawość wykazywał. Nie znamy wielu jego listów, ale znamy na nie odpowiedzi, które - chociaż ani pewne, ani dokładne - coś o tym mówią. Wszystkie tego typu zarzuty nie mają sensu, a wynikają z opacznego zrozumienia przekazu książki i idącej za tym arbitralnej jej oceny. Wątki z kolejnych zdarzeń w dziejach Rzeczypospolitej musiały zostać $\mathrm{w}$ pracy wskazane, bowiem miały one większy lub mniejszy wpływ również na to, co później głosił Świeykowski. To, co wiedział o zdarzeniach w kraju wpływało na jego poglądy i ich korekty, stąd chociażby zmiana nastawienia do Stanisława Augusta, co tłumaczę, ale celowo nie oceniam.

Parę słów o „gazeciarzu Gurskim” - tak nazwanym w recenzji (s. 594). Docenił go Jerzy Michalski i kilkanaście razy cytował ${ }^{5}$. Również dla mnie to ważne źródło, nie „gazeciarz”, a krewny Świeykowskiego, relacjonujący swe rozmowy z najbliższymi osobami z dworu królewskiego. W pracy wyjaśniono, że był on w Warszawie stale i blisko dworu, był też sekretarzem Rady Nieustającej. Napisałem nie „komunały”, a zwróciłem uwagę na to, co wynikało z przekazu Gurskiego kierowanego do Świeykowskiego. Owe „banały” Gurskiego pokazują ni mniej, ni więcej, tylko jak podchodzono do kwestii Dogrumowej zanim stała się ona narzędziem walki opozycji z królem w czasie sejmu 1786 r. Nie wiemy, czy i w jakim stopniu sprawa Dogrumowej zajmowała Świeykowskiego, a w ogóle musiała? Nie dotyczyła go bezpośrednio, podobnie nie angażował się w większość spraw dziejących się w Warszawie, jeśli te nie dotyczyły jego własnych interesów albo bliskich mu osób. Sprawa Dogrumowej była więc tylko płaszczyzną rozgrywania trwającego konfliktu, a nie jego sednem, do którego odnosiłby się Gurski. Stąd sformułowania ,jakiś angielczyk”, „niejaka Angielka” świadczą o tym, jak ta sprawa była postrzegana. I z pewnością jest to fragment na temat. Istotna uwaga, że we wszystkich fragmentach recenzji z adnotacją: "nie na temat”, nie są to przypadkowe rękopisy, lecz w większości albo relacje kierowane do Świeykowskiego, albo te, które znalazły się w jego archiwum nieprzypadkowo, co nadaje im wage przy próbach zrozumienia zachowań tego człowieka.

Moje „pozbawione dowodów domysły” (s. 594) w kwestii Gurskiego i jego prośby o wsparcie do poselstwa - zazwyczaj gazeciarze nie mieli

${ }^{5}$ Por. J. Michalski, Studia Historyczne z XVIII i XIX wieku, t. 1: Polityka i społeczeństwo, Warszawa 2007, s. 236, 254, 255, 257, 276, 296, 297, 304, 479, 485, 486, przy czym ani razu nie zakwestionował wartości przekazu Gurskiego czy jego obserwacji i napisał o nim: „Baczny obserwator”, ibidem, s. 296. 
takich ambicji, on miał - to kolejny nieuzasadniony zarzut. Czy na pewno ja powinienem być adresatem „sic" wprowadzonego w odnośnym miejscu recenzji? Na podstawie tego, że pytanie o poparcie jego kandydatury do funkcji poselskiej padło 10 miesięcy przed sejmikami, Recenzentka dochodzi do wniosku, że Świeykowski nie miał na to żadnego wpływu i moje sugestie o potencjalnym jego wpływie na elekcje poselskie są zupełnie błędne. Wydaje się, że 10 miesięcy to czas jak najbardziej właściwy i normalny, by zacząć starania o poselstwo. Czy naprawdę myliłby się Gurski, który znał przecież dobrze Świeykowskiego i wiedział, że ten ma możliwości oddziaływania? Był wtedy Świeykowski wręcz u szczytu powodzenia. Oczywiście to „nie żaden dowód”, a prawdopodobna przesłanka. Niemniej bez problemu w 1786 r. Świeykowski umieścił Gurskiego w gronie urzędników obsługujących Radę Nieustającą w randze sekretarza, o co, kto wie, czy nie było trudniej niż o poselstwo. W książce tylko „przypuszczam”, nie dowodzę, dlaczego nie chciał Świeykowski, by Gurski został posłem, on miał pilnować jego spraw w stolicy. Podobnie nie zostały zrozumiane uwagi o zainteresowaniu sejmikami 1786 r. Świeykowski interesował się nimi w zakresie takim, w jakim było mu to potrzebne, co właśnie odnośny fragment ukazuje. Dobór źródeł nie jest tu przypadkowy, a wynika ze wspomnianej zasady, że mają one pokazywać to, co wiedział o tych sprawach bohater, stąd są to listy kierowane do niego, innych bowiem materiałów to pokazujących nie odnaleziono.

Co się tyczy majątku Świeykowskiego, to ci badacze, którzy o nim wzmiankowali, zostali wymienieni, a że na tych stronach książki dominują rękopisy, wynika z tego, iż na poważnie nie zajmowano się wcześniej majątkiem ostatniego wojewody podolskiego. „Typy posesji” - co stoi w sprzeczności z zarzutem, że źródła są niepotrzebnie wykorzystywane były wskazywane za nimi, najczęściej w oparciu o papiery procesowe albo wskazujące na konkretne zapisy, kontrakt, akt kupna itp. Ponadto zmieniał się stan prawny niektórych włości. Nieścisłości w tej materii nie dało się wyjaśnić. Często nie wiemy, jakim prawem Świeykowski trzymał jakieś dobra. Są wskazania źródłowe tego, z czego korzystałem, można iść tym torem i szukać finału konkretnych spraw, może kiedyś komuś uda się dotąd niewyjaśnione do końca procesy rozplątać, ale nie wiem, czy i na ile zmienią one portret wojewody. Zresztą w założeniu każdej pracy badawczej jest, że ktoś pójdzie wskazaną ścieżką, w tym przypadku zajmie się porządkowaniem form własności w dawnej Rzeczypospolitej, to przecież problem prawie niedotknięty przez historyków. Ta sama uwaga dotyczy toczonych procesów. Myślę, że każde w nie wniknięcie może dać przesłanki do innej oceny faktu angażowania się przez szlachtę w procesy. Poruszana w kontekście ekonomicznym kwestia obecności 
wojsk moskiewskich na ziemiach Rzeczypospolitej dotyczyła także bezpośrednio majątków Świeykowskiego. Problem ten - już w odniesieniu nie tylko do majętności mojego bohatera - wymaga osobnego ujęcia monograficznego ${ }^{6}$, nie znam takiego, więc w tym szerszym kontekście problem jest tylko wzmiankowany właśnie po to, by nie odchodzić od tematu, a wskazać jego znaczenie we właściwych proporcjach. Chybiony jest zarzut o nieporównywaniu majątku Świeykowskiego z innymi. Jego majątek „usadowiono” w hierarchii „bogaczy”, co było istotne dla tematu, sam wojewoda zresztą czynił, choć w niewielkim wymiarze, takie zestawienia, i jest to pokazane w książce. Jego majątek został porównany $z$ innymi i lokowany w pierwszej dziesiątce największych fortun południowo-wschodnich kresów Rzeczypospolitej. Szersze porównywanie funkcjonowania jego folwarków z innymi nie było tematem pracy, ta dotyczy kariery średniozamożnego szlachcica, do której majątek był kluczem. Oczywiście, porównywanie funkcjonowania majątków szlachty ma głęboki sens, ale w odrębnym ujęciu monograficznym.

Sprawa usunięcia magazynów rosyjskich bynajmniej nie jest pokazana jako rewelacja, ale jako jedyny czynny udział Świeykowskiego w działaniach publicznych w okresie Sejmu Wielkiego. Kilkanaście stron w biografii zostało poświęcone relacjom obywateli wschodnich kresów Rzeczypospolitej z Rosją i Rosjanami, zwrócono uwagę na fakt, jaki one miały charakter i jak były istotne. W tym kontekście zachowanie Świeykowskiego, moim zdaniem, powinno skłaniać do refleksji: oto ktoś, kto na kontaktach z Moskwą zyskiwał, wykonuje wolę ogółu i magazyny „zamyka”. Ocena tego wątku w recenzji jest błędna i wynika chyba z chęci szukania błędów, a niedostrzegania sedna narracji, dorabianie do tego ideologii świadczy tylko o złej woli Recenzentki, albo niezrozumieniu przez Nią ocenianego passusu. Jest przy tej okazji mowa o roli Prus w tych zdarzeniach, ale nie o „prowokacji” Prus, jak napisano w recenzji, to nadinterpretacja, taka była polityka Prus i nic więcej. Żaden ze wskazywanych autorów których jakoby pominąłem - o roli Świeykowskiego w tych zdarzeniach nie pisze więcej niż napisano w biografii, a przecież nie jest to opracowanie monograficzne „dziejów magazynów” rosyjskich w Polsce czasów stanisławowskich, lecz, powtórzę, biografia Świeykowskiego. Cenniejsze więc niż przywoływanie literatury - która w tym punkcie nie wnosi nic nowego do biografii - było odnotowywanie w przypisach nieznanych

${ }^{6}$ Napisałem trzy artykuły, w których wątek ten pojawiał się w proporcjach i kontekstach odpowiednich do podejmowanych tematów, ale nie uważałem za konieczne przywoływać ich w przypisach w książce. Problem wymaga opracowania od podstaw, a doświadczenia Świeykowskiego z Rosją i jej wojskami na terenach Rzeczypospolitej są kolejną „,cegiełką” do jego realizacji. 
albo marginalnie wykorzystywanych rękopisów. Podobnie odpowiadam w odniesieniu do zarzutów dotyczących buntów $1789 \mathrm{r}$. Tu z dodatkiem: skąd się wziął zarzut, że nie znam pojęcia „mało Rosja” - „Małorosja", nie wiem. Owo pojęcie pojawia się tylko w cytowanym przypisie. W kwestii ochłodzenia stosunków Świeykowskiego z królem napisałem to, co można było wnioskować na podstawie korespondencji wojewody, nikt o tym więcej nie pisał. Zaznaczyłem również, jakie mogły być przyczyny ochłodzenia tych relacji. Dlaczego jednak uznano, że nie jest to na temat, tego nie wiem. Józefa Świeykowskiego stolnika owruckiego nie sprawdziłem, to mój błąd, również proces o „Czarną Kamionkę” faktycznie nie był procesem granicznym, ale nie był też procesem Leonarda Marcina Świeykowskiego, na którego sprawach się skupiałem. Chodziło tylko o fakt, że pojawiał się w procesie Leonard Marcin Świeykowski, który na prośbę Stanisława Augusta miał pomagać Stanisławowi Szczęsnemu Potockiemu, tak by nie ciążyła na nim kondemnata i mógł brać bez przeszkód udział w życiu publicznym. Tu nie proces był istotny, a, w kontekście biografii, jego wydźwięk.

W kwestii pozostałych wytkniętych mi błędów przyznaję, że sprawę nominacji Świeykowskiego na wojewodę podolskiego niepotrzebnie zagmatwałem i ponadto $\mathrm{z}$ niedopatrzenia nie sprawdziłem daty nominacji w Urzędnikach podolskich. Być może rzecz wydawała mi się w danym momencie zbyt prosta i oczywista, choć nie dla ówczesnych. Natomiast rzeczony spis jest wykorzystany w celu sprawdzania urzędów ${ }^{7}$. Błędne przesunięcie o miesiąc daty nominacji Świeykowskiego nie wpływa na żadne inne wątki omawiane w biografii.

„Kapitanowie Lędzki i Poletyła” (s. 596) rzeczywiście mi zaszkodzili. Ich nie zweryfikowałem, a korzystałem ze swoich notatek czynionych z mikrofilmu w 1997 r., gdzie zapisani byli w nawiasie kwadratowym ze znakiem zapytania; jak wygląda stosowny zapis w oryginale, rzecz jasna, nie pamiętałem. To nie usprawiedliwienie, ale stwierdzenie faktu. Zresztą akurat podawanie zastępców mogłem pominąć, to faktycznie - czego nie wskazano w recenzji - urywek nie na temat. Niemniej mój błąd stał się pretekstem do półstronicowego akapitu w recenzji, czy naprawdę warto? W zagajeniu do rozdziału o poglądach politycznych Świeykowskiego pojawia się pismo Juliana Ursyna Niemcewicza Forma Prawdziwego Wolnego Rządu. Faktycznie nie przypisałem jego autorstwa Niemcewiczowi, to mój błąd, ale z jego rangą bym nie przesadzał, chodziło o zagajenie do rozdziału. Treść tego pisma, w którym krytykowano pomysły ustrojowe targowiczan, do tego bardzo dobrze się nadawała, poniekąd odpowiedzią

\footnotetext{
${ }^{7}$ Por. D. Rolnik, Leonarda Marcina Świeykowskiego (1721-1793), s. 134.
} 
na nią były projekty Świeykowskiego. Był to zabieg potrzebny do konstrukcji rozdziału, a nie analiza samego pisma. W rozdziale tym, prezentującym całość poglądów wojewody, musiały się znaleźć powtórzenia wątków wcześniej podawanych w innych kontekstach. Materia myśli politycznej jest, jak wnioskuję, bardzo drażliwa dla badaczy, często przekonanych o własnych racjach, a opartych na pismach uznanych myślicieli i twórców myśli politycznych, przy czym nie rozumiem mechanizmu przypisywania ich przez badaczy ogółowi albo większości narodu szlacheckiego. Ja własne komentarze w tym rozdziale ograniczyłem do minimum, co wynika nie z mojej nieznajomości tej materii, ale z odmiennego podejścia do niej. Jest ważne w moim przekonaniu, że autorem jednej z koncepcji - może nieoryginalnej, może niedojrzałej lub nawet głupiej, ale w miarę pełnej - był Świeykowski, zupełnie nieznany dotąd w kręgu twórców myśli politycznej. Myślę, że wskazanie na niego w tym kontekście jest jakąś wartością dodaną zawartą w książce. W pracach - wspomnianych przez Recenzentkę, a które znam - badaczy zajmujących się myślą polityczną, o Świeykowskim nikt nie wspomina. Gdybym na podstawie jego przekazu zastanawiał się np. nad myślą ustrojową, to prace wskazanych autorów - i niewskazanych - bym nie tylko wykorzystał, ale i szerzej przeanalizował, jednak nie taki był mój zamysł. „Co należy sądzić" o instrukcjach poselskich czy o wyborze senatorów na sejmikach pewną wiedzę mam, znam również poglądy badaczy na ten temat, ale dla mnie nieustannie ważniejsze było, co sądził o tym Świeykowski ${ }^{8}$. I to jego stanowisko, wiedzę i niewiedzę opisuję. W całym fragmencie poświęconym temu zagadnieniu $\mathrm{w}$ recenzji, krytyka paradoksalnie dotyka więc Świeykowskiego. W książce nie oceniałem i nie wartościowałem poglądów ostatniego wojewody podolskiego, tylko je przedstawiłem, aneks zaś służyć miał jako pomoc dla tych, którzy chcą oceniać, które myśli były „lepsze”, które „gorsze”, czy był - czy nie - republikaninem. Natomiast zwracałem uwagę na fakt, że Świeykowski ogarniał swym rozumem prawie wszystkie aspekty funkcjonowania ówczesnego społeczeństwa oraz państwa, chociażby dlatego warto zauważać to, co miał do powiedzenia, nawet jeśli się mylił. Takich „domorosłych” myślicieli było wówczas więcej, są oni często zupełnie nieznani, warto ich z tego niebytu wydobywać. Zapisane ich myśli mogą bowiem pokazywać, że korektom musi ulec treść opracowań traktujących o rozwoju polskiej myśli politycznej. Być

${ }^{8}$ Ponadto sugeruję, że wybierano starostów grodowych i urzędników sądowych i w tych kwestiach dyskusja toczyła się na innym poziomie i emocji wielkich - poza jednostkowymi przypadkami - nie wywoływała. To również problem niedyskutowany w literaturze historycznej. 
może praca zyskałaby na połączeniu dwóch ostatnich rozdziałów, ale chciałem wyeksponować „myśl polityczną” człowieka, który z niczego doszedł do godności senatorskich i wielkich majętności, i który osiągnął to wszystko pracą nie tylko swoich rąk, ale i głowy.

Kwestia postaci, które są mylone: czy pomieszałem Kazimierza z Andrzejem Poniatowskim (s. 598), nie mam pojęcia, w recenzji nie wyjaśniono, na jakiej podstawie zarzuca mi się pomyłkę. Mnie chodziło w tych akapitach o pokazanie bliskości Świeykowskich z Familią. Zarzucanie mi na tej kanwie „dezorientacji w hierarchii urzędników” i to na poziomie „skarbnika” sugeruje, że powinienem pewne partie skrócić, by stały się zupełnie jasne i jednoznaczne. O tej kwestii pisałem na paru stronach, chodziło o ustalenie osoby, ważnej ze względu na rolę, którą mogła pełnić pod koniec 1763 r., być może konkretnie o Świeykowskiego. Ja jej do końca pewny do dziś nie jestem, ale Recenzentka na tej podstawie stawia mi zarzut ogólniejszy, że nie orientuję się w urzędnikach (s. 598). W gruncie rzeczy z tym zarzutem mogę się zgodzić, ale warto przejrzeć kilka ksiąg grodzkich, zwrócić uwagę na to, kto, jak i czym się podpisuje, jak sygnuje swą korespondencję, może się zdarzyć, że każdy „podpis” jest inny. $Z$ tych niejasności wynika - mimo tego, że 30 lat zajmuję się epoką stanisławowską - brak mojej pewności co do własnej wiedzy, ale mam świadomość tych niejasności. Spisy urzędnicze porządkują pewne rzeczy, ale w pewnych przypadkach właściwej identyfikacji postaci, szczególnie urzędów niższej rangi, są również bezradne. Często twórca źródła sam nie wiedział dokładnie o kogo chodzi, dobrze, jeśli nie przekręcał nazwiska. Przekręcano też nazwisko ambasadora moskiewskiego Ottona Stackelberga. Problem to bynajmniej niebanalny, pokazuje, co dla kogo było ważne i kim w prowincjonalnej hierarchii ważności był "Siakerberk". To trochę gwoli wytłumaczenia moich braków w poprawnych zapisach postaci. Jednego Antoniego Tyzenhauza - przyznaję się do błędu - pominąłem w indeksie, natomiast w tekście zawsze wiadomo, czy chodzi o Tyzenhauza podskarbiego, czy o Tyzenhauza posła wileńskiego. Postacie te nie zostały ani razu pomylone, zatem, co mnie cieszy, wbrew sugestii w recenzji, rozróżniam dwóch Antonich Tyzenhauzów. Komentarz Recenzentki jest tyle złośliwy, ile nierzetelny (s. 595).

Do indeksu osobowego Recenzentka również wyraziła krytyczne uwagi (s. 598), jego poziom jej nie zadowolił. Ja jego błędy / usterki również dostrzegam, ale oceniam je liberalniej. Niektóre postaci nie zostały w nim odnotowane - np. wspomniany Antoni Tyzenhauz - albo nie zostały prawidłowo zidentyfikowane. Na usprawiedliwienie zwracam uwagę, że indeks liczy przeszło 1200 postaci i zajmuje 20 stron. W większości nie są to osoby znane, a raczej takie, których nie odnajdziemy 
w spisach urzędników. Teoretycznie w wielu fragmentach, czy to tekstu, czy źródeł mogłem te osoby potraktować „trzema kropkami”, ale przecież chciałem pokazać również ludzi mniej znanych, których, po pierwsze, ktoś w swych badaniach może poszukiwać, po drugie, może wśród nich znajdzie się jakiś „Świeykowski” dotąd nie zidentyfikowany, a ponadto oni $\mathrm{w}$ większości kontaktowali się z Leonardem Marcinem Świeykowskim. Indeks pokazuje również krąg, skalę i zasięg jego kontaktów, a przez to także ich rozległość. Pominięcia i błędy wskazane w recenzji są oczywiście moimi niedociągnięciami, ale nie mogę się zgodzić z wnioskiem: „tak niesolidnie sporządzony indeks nie służy do niczego" (s. 598). Uwagi dotyczą przekręcenia nazwisk czy nieobecności w indeksie kilku postaci - przyznaję, zdarzyło się, umknęły mojej uwadze, natomiast indeks sporządzony został - wbrew temu co sugeruje Recenzentka - według jasnych reguł, zaznaczono, że nie obejmuje tylko „Leonarda Marcina Świeykowskiego" 9 . Osoby w indeksie pominięte albo właściwie niewskazane, tak tych współczesnych, jak potomków postaci historycznych oraz badaczy czasów stanisławowskich, przepraszam. Zasugerowano w recenzji, że przydałby się indeks miejscowości, owszem, jak najbardziej tak, ale na to brakło czasu, sił i pojemności książki.

Ostatni problem, o którym chcę wspomnieć, to wypomniane w recenzji powtarzanie zapisów źródeł z „,wielowierszowym” opisem (s. 593, 598). Taką zasadę przyjmują jedne wydawnictwa, podczas gdy inne zadowalają się numerkiem rękopisu i bez podania stron; wolę ten rozleglejszy zapis. Ułatwia on pracę chyba nie tylko potencjalnym recenzentom, ale również badaczom. Przypisy odnoszące się do załączników - drugiej części (aneksu) mogły być krótsze i z wielu można było zrezygnować, ale może dzięki nim ma ona szansę funkcjonować jako odrębna całość.

Pozostając przy kwestii przypisów. Rozległe Archiwum Świeykowskich z jego przyległościami jest prawie w ogóle nieznane, zostało, w moim mniemaniu, przyzwoicie i krytycznie odczytane i zaprezentowane nie w „niemal 3 tys.” przypisach, jak to policzyła Recenzentka (s. 597), a w przeszło 3,5 tys. (nie licząc literowych odniesień w aneksie) - drobna nieścisłość? Z tego (liczby przypisów) wynikają - niepowtarzane w jednym rozdziale, co jest zasadą uznawaną w poważnych naukowych wydawnictwach - pełne opisy źródeł. W trakcie pracy wątpliwości co do odczytania, wartości, interpretacji tego materiału było sporo, przy tym trzeba zauważyć, że większość to pisma różnych osób, a nie o wiele łatwiejsza do odczytania i opracowania korespondencja dyplomatyczna czy króla, pisana jedną ręką albo przez jego sekretarza.

9 Por. D. Rolnik, Leonarda Marcina Świeykowskiego (1721-1793), s. 725. 
W tym kontekście warto może spojrzeć również na obszerność bazy źródłowej, będącej podstawą opracowania biografii ostatniego wojewody podolskiego. Nie odsyłam w tym momencie do bibliografii zamieszczonej w pracy, bo to prosty wykaz sygnatur z „tytułami” jednostek, ale z linijką do archiwów i bibliotek. To, co zostało w pracy wykorzystane i ujęte w bibliografii, to kilkanaście metrów bieżących akt (nie liczę materiałów przejrzanych, a niewykorzystanych) rozproszonych po kilkunastu archiwach i bibliotekach.

Podsumowując moją biografię, Recenzentka napisała: „To co otrzymaliśmy, nie ma nic wspólnego z historiografią", chociaż z definicji pojęcia „historiografia” wynika, że jednak ma ${ }^{10}$. I dalej pisze, konkludując: publikacja „nie spełnia reguł poprawnej warsztatowo historiografii”. Zyskujemy więc nową definicję pojęcia historiografia, dzieli się ona na poprawną i niepoprawną warsztatowo (s. 597, 600).

Ze wskazanymi w recenzji błędami zapisów w większości, jak napisałem, zgadzam się, natomiast nie mogę uznać krzywdzącej konkluzji podważającej mój warsztat. $Z$ tym nie mają one nic wspólnego, to najczęściej błędne odczyty końcówek części fraz źródła. Owszem, nie powinno ich być, ale materiał wykorzystany przy pracy nad biografią Świeykowskiego to nie raporty dyplomatyczne lub listy pisane przez sekretarzy dyplomatów. Źródła będące podstawą biografii to niewykorzystywane dotąd prawie $\mathrm{w}$ ogóle materiały rękopiśmienne, a bez wątpienia nigdy w takiej skali, jak miało to miejsce w recenzowanej pracy. Również skala i waga błędów w stosunku do odczytanego i zaprezentowanego materiału źródłowego jest w moim odczuciu minimalna, w żadnym momencie moje potknięcia nie wpływają na błędny odczyt źródła i jego interpretację w biografii Świeykowskiego. Obszerne Archiwum Świeykowskich to archiwum rozproszone, w którym - przysłowiowo - trudno znaleźć dwa pisma pisane tą samą ręką. Może gwoli usprawiedliwienia - ale trzeba też nadmienić, że to nie jest praca nad jednorodnym korpusem źródeł liczącym przykładowo sto listów jednej proweniencji - biografia została zbudowana w oparciu o analizę paru tysięcy listów, pism, dokumentów sądowych. Poskładanie tych źródeł różnych gatunków i różnego pochodzenia w jedną całość bez dobrego warsztatu nie jest możliwe, a w odczuciu piszącego to się jednak udało.

Do koncepcji pracy i jej przesłania Recenzentka nie odniosła się. Ominęła więc szerszy kontekst dotyczący żywota i kariery Leonarda Marcina Świeykowskiego. Z zaprezentowaną przeze mnie jej wizją można dyskutować, ale tego nie uczyniono. Celem moim było pokazanie postaci

${ }^{10}$ Historiografia, w: Encyklopedia powszechna PWN, t. 2, Warszawa 1974, s. 210-211. 
drugoplanowej w życiu publicznym czasów stanisławowskich aspirującej do wyższych godności, i ten cel zrealizowałem. Opracowanie biografii Świeykowskiego, mieszczące się w nurcie badań nad społeczeństwem czasów stanisławowskich, wyjaśnia wiele meandrów na drodze budowy karier średniego szlachcica, mechanizmów budowy kręgów towarzyskich, wskazuje na kryteria wartości i sposób myślenia o państwie średniej szlachty z aspiracjami, w końcu pokazuje schemat postępowania przy tworzeniu stronnictwa Stanisława Augusta, a przy tym jego słabości i walory. W biografii Świeykowskiego zawiera się model kariery przeciętnego obywatela, w książce pokazane zostały sposoby dochodzenia do wyróżnień, sposób myślenia o społeczeństwie, o poddanych i o wielu kwestiach szczegółowych. Jest w niej wiele przykładów uzupełnień czy dopełnień w licznych drobnych, ale ważnych sprawach, z których badacze drugiej połowy XVIII w. mogą korzystać, i które w moim odczuciu są niezbędnym warunkiem do zrozumienia czasów stanisławowskich. Tego Recenzentka nie zauważyła w ogóle, ponieważ nie było chęci ku temu, dobrej woli i po prostu obiektywizmu. W zamian, mentorskim tonem i koncentrując się na szczegółach, zdezawuowała wszelkie moje ustalenia, realizując swój z góry założony cel, albo - czego nie wykluczam - jej metodologia ogranicza się do sprawdzania poprawności zapisów źródeł, a to jednak niewiele w pracach nieodtwarzających tylko faktów, ale również pewne szersze zjawiska. Jej uwagi traktuję nie jako rzetelną ocenę mojej pracy, ale jako erratę do niej, owszem, potrzebną, ale nic więcej, zresztą nawet w bardzo dobrej książce czasami musi ona być. Mam również nadzieję, że skrajnie pejoratywnej opinii zaprezentowanej w recenzji nie podzielą znawcy przedmiotu, badacze dziejów Rzeczypospolitej stanisławowskiej, a dalsze badania zweryfikują, czyj sposób postrzegania tej epoki - mój czy Zofii Zielińskiej - był właściwszy.

Biogram: Dariusz Rolnik - dr hab., prof. Uniwersytetu Śląskiego, pracownik Instytutu Historii UŚ w Katowicach. Zajmuje się dziejami Rzeczypospolitej czasów panowania Stanisława Augusta (1764-1795), a szczególnie dziejami społeczeństwa szlacheckiego tego okresu; prowadzi badania nad postawami szlachty państwa polsko-litewskiego, jej stosunkiem do króla i instytucji państwa oraz do kwestii zagrożenia bytu (sprawa postrzegania rozbiorów) i suwerenności szlacheckiej Rzeczypospolitej (zachowania wobec Rosjan); kontakt: dariusz.rolnik@us.edu.pl. 